\title{
Financial Inclusion in India - a Review of Initiatives and Achievements
}

\author{
Sonu Garg ${ }^{1}$, Dr. Parul Agarwal ${ }^{2}$, \\ ${ }^{I}$ (School of Management, JECRC University, Jaipur, Rajasthan, India) \\ ${ }_{2}^{2}$ (Director, School of Management, JECRC University, Jaipur, Rajasthan, India)
}

\begin{abstract}
Finance has become an essential part of an economy for development of the society as well as economy of nation. For, this purpose a strong financial system is required in not only in under-developed countries and developing countries but also developed countries for sustainable growth. Through Financial inclusion we can achieve equitable and inclusive growth of the nation. Financial inclusion stands for delivery of appropriate financial services at an affordable cost, on timely basis to vulnerable groups such as low income groups and weaker section who lack access to even the most basic banking services. In this paper, the researcher attempts to understand financial inclusion and its importance for overall development of society and Nation's economy. This study focuses on approaches adopted by various Indian banks towards achieving the ultimate goal of financial inclusion for inclusive growth in India and analyses of past years progress and achievements. The relevant data for this study has been collected with the help of from various Research journals, Articles, reports of RBI, reports of NABARD and online resources.
\end{abstract}

Key words: Financial inclusion, Financial Exclusion, Business correspondents, KCCs, GCCs.

\section{Introduction:}

The process of economic growth, especially when it is on high growth line, must attempt to take participation from all sections of society. Lack of access to financial services for small/ marginal farmers and weaker sections of the society has been recognized as a serious threat to economic progress, especially in developing countries.

The recent developments in banking technology have transformed banking from the traditional brickand-mortar infrastructure like staffed branches to a system supplemented by other channels like automated teller machines (ATM), credit/debit cards, online money transaction, internet banking, etc. The moot point, however, is that access to such technology is restricted only to certain segments of the society. Many of research reports and surveys clearly show that large numbers of population does not have an access to basic banking and financial services not only in India but also whole world. This is termed "financial exclusion". These people, particularly, those living on low incomes, cannot be access mainstream financial services and products such as bank accounts which are used for making payments and keeping money, remittances, affordable credit, insurance and other financial services, etc.

\section{Objectives of the study:}

This research paper has four main objectives:

1. To understand the financial exclusion and its extent.

2. To understand the financial inclusion and its importance.

3. To find out the approaches adopted by banks, steps taken by the regulatory bodies and various government initiatives to achieve financial inclusion.

4. To analyze the past years performance and achievements towards reaching out to the unbanked areas under financial inclusion.

\section{Concept of Financial Exclusion:}

Before we understand financial inclusion we should have knowledge about financial exclusion. The word of financial exclusion first time used in 1993 by Leyshon and thrift who were concerned about limited access on banking services as a result number of bank branches were closed. In1999, kempson and whyley defined financial exclusion in border sense which refers to those people who have excluded access to mainstream financial services and product till date numbers of analysts added their views to define financial exclusion.

'Financial exclusion' describes as a situation in which people do not have access to mainstream financial product and services such as banks accounts, credit cards and insurance policies, particularly home insurance, education loan. The effects of financial exclusion can include exclusion from other mainstream services, such as pension or saving schemes, and can also lead to debt and/or cut off from essential utilities. 
According to the European Commission, Financial exclusion is: 'A process whereby people encounter difficulties accessing or using financial services and products in the mainstream market that are appropriate to their needs and enable them to lead a normal social life in the society in which they belong.'

In India, The Report of the financial inclusion in January 2008 by C Rangarajan, Financial exclusion is defined as restricted access to financial services to certain segment of the society. Generally, this large section of the population comprises individuals or family falling into low income groups, which are not able to access even the most basic banking services like bank accounts, credit, insurance, financial advisory services and payment services. So basically, financial exclusion is the situation where certain group of population is excluded or unable to access low cost an appropriate mainstream financial products and services.

\subsection{Extent to financial exclusion in globally:}

As per the report of the World Bank, in survey of 148 economics approximately 2.5 million people do not have an bank account and totally excluded from mainstream financial services and products. They do not have access to affordable financial services which is an ultimate tool for overcoming poverty and minimize income inequalities.

As per the world bank report only 50 percent adults population have an account in formal financial institutions while rest of remain unbanked. Where 54.7 percent male adults have an account in formal financial institutions, only 46.3 percent female adults have an account. This report reveals that 20.9 percent adults use an account to receive their wages and only 22.4 percent adults saved at formal financial institutions in the past year. 9.0 percent adults have taken loan from formal financial institutions in the year of 2011.

55 percent of borrowers in developing countries use only informal source of finance. Not only financially excluded people require the banking services but obstacle such as cost, distance and documentations create very critical situation.

\subsection{Financial exclusion in India:}

India is place of the largest unbanked population where, only 35 percent adults having an account in financial institutions which shows that percentage of account penetration in India just below rest of the developing world. About 50 percent of adults reports in Andhra Pradesh and Delhi NCR and 40 percent in Gujarat, Kerala, and Maharashtra having a formal account but Bihar, Orissa, and Rajasthan reports less than 30 percent account penetration. As per data available from Census 2011, India is having population of around 1.22 billion and 65 per cent of adults across the country are excluded from the formal financial system. As per the report of World Bank, In India, only 35.2 percent adults above the age of 15 years have an account at formal financial institutions. 55 percent population has deposit accounts and only 9 percent population have credit accounts with formal financial institutions. Reports show that there is one bank branch per 14,000 persons. Just 18 percent are debit card holders and less than 2 percent are credit cards holders. In India, despite expansion of bank branches post reform period, the total branches of commercial banks including RRB's and SCB's has still stood only 48000 in a country to provide service to 6 lakh villages. So there is only one bank branch over the 12.5 villages. In India and other BRICS economies unbanked respondents reported obstacles to access formal accounts.

Figure 1: Self - reported barriers to use of formal accounts

Non- account holder reporting barrier as a reason for not having an account $(\%)$

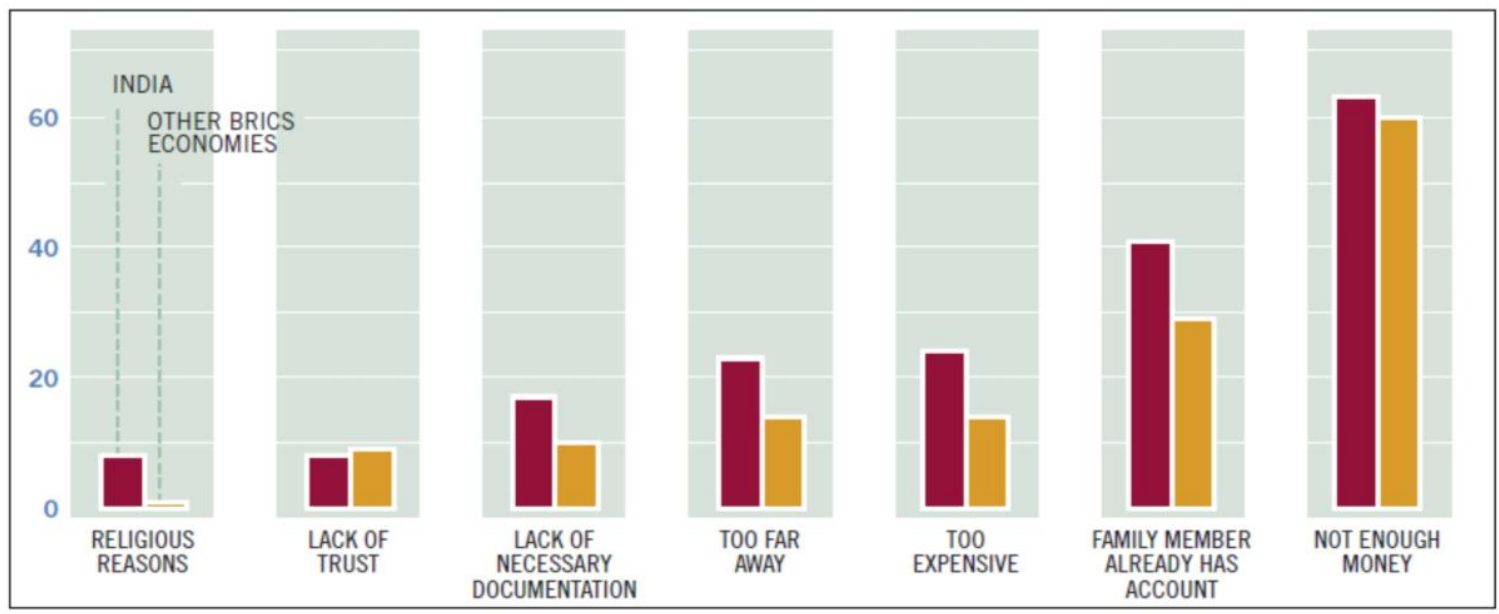

Source: Demirguc-Kunt, Asli; Klapper, Leora; Randall, Douglas, The Global Findex Database: financial inclusion in India

Note: Respondents could choose more than one reason. Other BRICS economies comprises Brazil, Russia, China, South Africa. 
The most common reason for not having a bank account in formal financial institutions is lack of enough money, a barrier reported by 63 percent of unbanked adults. The second major reason: a family member already having an account was cited by 41 percent respondents. Distance, cost, and lack of necessary documentation were each cited by about 20 percent of unbanked respondents, rates exceeding those in other BRICS economies.

Thus, financial inclusion has become equally important issue of under - developed, developing and developed economies for inclusive growth. Through the process of financial inclusion we can overcome the situation of the financial exclusion.

\subsection{Concept and Definition of Financial Inclusion:}

\section{Financial Inclusion :}

Financial inclusion is one of the most important aspects in the present scenario for inclusive growth and development of economies. The financial inclusion term was first time used by British lexicon when it was found that nearly 7.5 million persons did not have a bank account. But financial inclusion concept is not a new one in Indian economy. Bank Nationalisation in 1969, establishment of RRBs and introduction of SHG- bank linkage programs were initiatives taken by RBI to provide financial accessibility to the unbanked groups.

According to committee on Financial inclusion headed by Dr. C. Rangarajan defined financial inclusion as "The process of ensuring access to financial services and timely and adequate credit where needed by vulnerable groups such as weaker sections and low income groups at an affordable cost." Financial inclusion does not stand for delivery of financial services for all at all cost. But it means that the delivery of financial services and products at affordable costs of excluded sections of population and low income groups. It plays a crucial role to remove away the poverty from the country. Financial inclusion is to provide equal opportunities to vast sections of population to access mainstream financial services for better life, living and better income. It provides path for inclusive growth.

Financial inclusion can be described as the provision of affordable financial services, viz saving, credit, insurance services, access to payments and remittance facilities by the formal financial systems to those who are excluded. So, financial inclusion refers to access to vast range of financial product and services at affordable cost. It not only includes banking products but also other financial services such as loan, equity and insurance products.

Figure 2: Household Access to Financial Services

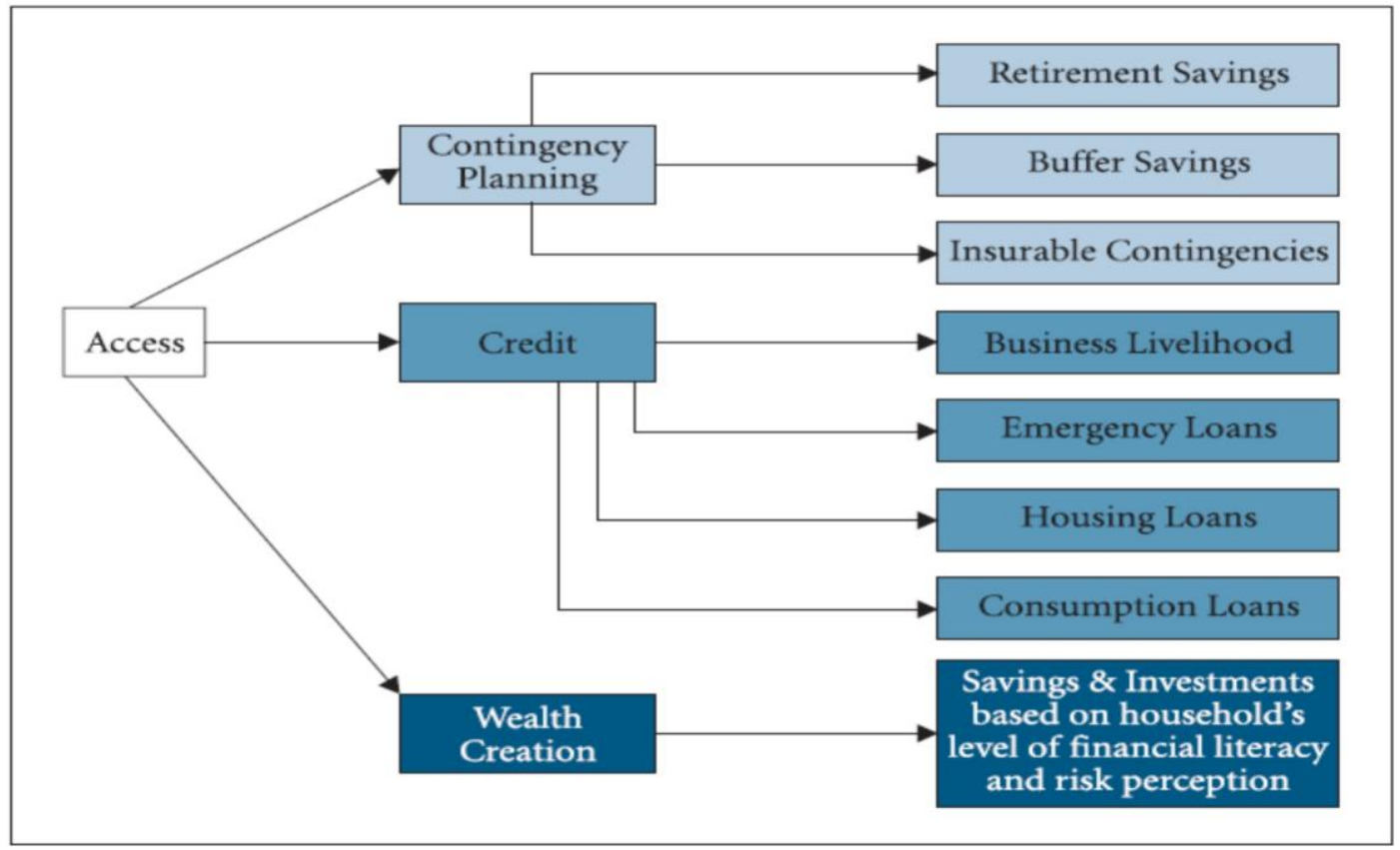

Source: A Hundred Small Steps a Report of the Committee on Financial sector reforms by Raghuram G. Rajan

Households need access to finance for several purposes like creating buffer, retirement, saving to hedge against unpredictable situations and take products for insurable contingencies. Household also needs access to credit for livelihood creation, housing, consumption and their emergencies. Finally households require financial services to access a wide range of saving and investment products for wealth creation but it is all depends upon their level of financial literacy. 


\subsection{Importance of financial inclusion:}

Easy access to financial services will allow the population leaving in lower strata, to save money safely and help in preventing concentration of economic power with a few individuals, thus mitigating the risks that the poor could face as a result of economic shocks. Therefore, providing access to financial services is becoming an area of concern for the policymakers as it has far reaching economic and social implications.

In India, The single most frequently used source of loan for medium Indian household is still moneylender. Large parts of our financial system are still hampered by political intervention and bureaucratic constraints, limiting their potential contribution. India's poor, many of who work as agricultural and unskilled semi skilled wage laboures and low salaried workers are largely excluded from the formal financial system. Even micro and small enterprises, find it difficult to have an access to formal sources of finance and thus are largely excluded from financial system. Over $40 \%$ of India working population earn but have no saving. Financial inclusion provides protection to poor from the control of the spurious money lenders.

\section{Various approaches to achieve financial inclusion:}

In India, various measures taken by banks, GOI and RBI for financial inclusion plan. Figure 3 highlighted currently adopted financial inclusion approaches.

Figure 3: Financial Inclusion : Currently adopted Approaches

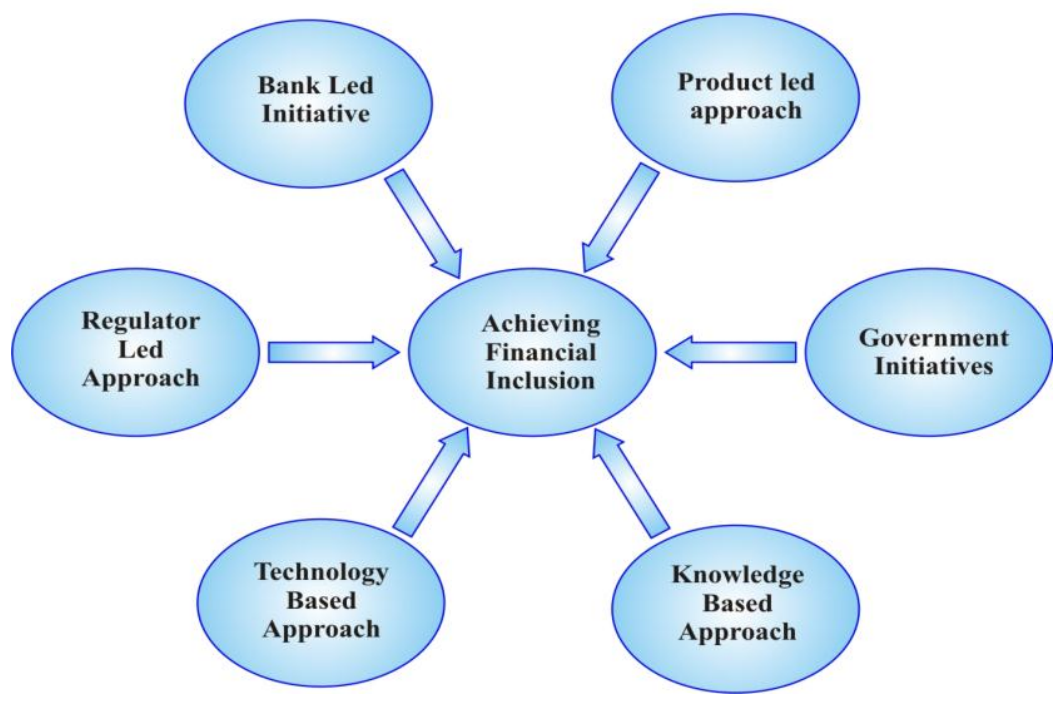

5.1 Product Based Approach: Reserve bank of India has been proactive, liberal and supportive while making policies so as to enable financial institutions to come up with innovative products for enabling a common man to get the benefit of the financial inclusion plan. Some products developed for fulfillment of this approach have been mentioned in this paper.

i. No- Frills Account (NFAs):- This concept was introduced by RBI in November 2005 to provide access to basic baking services by financially excluded peoples. Under this approach banks open accounts with zero balance or very minimum balance requirement for the under-privileged. In 2012, the banks under RBI guidelines came-up with a better version of the no-frill accounts where they would open Basic Savings Bank Deposit Accounts (BSBDAs) for all individuals with the facility of debit card, cheque book, internet banking, overdraft limits at minimal charges. However, the number of transactions could be restricted so as to prevent misuse of such accounts.

ii. Kisan Credit cards (KCCs):- Under this scheme banks issue smart cards to the farmers for providing timely and adequate credit support from single window banking system for their farming needs. During 2012-13 (up to December 2012), public and private sector banks issued 1.2 million smart cards as KCCs.

iii. General Purpose Credit Cards (GCC) :- In 2005 Reserve bank of India, issue guidelines to banks that to provide General Purpose Credit Card (GCC) which facilitate credit up to Rs.25000/- without any collateral requirement for rural and semi urban people based on assessment of household cash flows. Now as per the revised guidelines in Dec.'2013 under this approach bank also fulfill Non- farm entrepreneurial credit requirement of individuals (e.g. Artisan Credit card, Laghu Udyami Card, Swarojgar Credit Card, Weaver's Card etc) There will be no ceiling on the loan amount as long as the loan is for the purpose of non-farm entrepreneurial activity and is otherwise eligible for classification 
as priority sector. Security norms will be applicable as per Reserve Bank guidelines on collateral free lending for micro and small units issued from time to time.

iv. Saving account with Overdraft facility: - Banks have been advised to provide overdraft (OD) facility in saving account and also Small Overdrafts in No-frills accounts. The setting up of the limit for the same would be done by banks considering the transaction in the account. This would help the customer to get easy access to the credit at lower rates.

\subsection{Bank Led approach:}

i. $\quad$ Self Help Group - Bank Led Initiative (SLBP):- The SLBP or Self Help Group - Bank Linkage Program has been the major institutional based innovation in India for enabling access and covering the gap of reaching financially excluded population of the country in the last two decades. In this model, the banks involve themselves with a group of local people with the idea of enabling them to pool up their savings. The same is deposited with the bank against which the bank also provides a certain amount of credit facility. The group takes a decision to whether to lend to any member of the group. The bank provides the framework, accounting services and support to the group to manage their deposits and lending. Thus the model has an approach of savings first, lending later. The banks do not have a risk in such lending as the borrower's reputation and peer pressure in the group would reduce the risk of bad loans considerably. However, The model has some issues that affect the program
a. Inadequate outreach in many regions.
b. Delays in opening of SHG accounts and disbursement of loans.
c. Impounding of savings by banks as collateral.
d. Non-approval of repeat loans by banks even when the first loan was repaid.
e. Multiple memberships.
f. Borrowings by SHG members within and outside SHGs.
g. Adverse consequences of unhealthy competition between NGO promoted SHGs.
h. Government promoted/subsidy oriented SHGs and limited banker interface.
i. Monitoring of the SHGs.

While the basics of the SHGs being savings led credit product remain true even today, recent developments have given rise to the need for relook in the approach and design of this fairly successful model leading to SHG -2 .

The basic features of SHG - 2 are

a. Voluntary savings apart from compulsory savings

b. Allowing the sanction of a cash credit / overdraft system of lending for SHGs for a longer operational tenure, and

c. Graduating selected members of the group that have entrepreneurship potential into a joint liability groups for borrowing larger amounts.

ii. Business Facilitators (BFs)/Business Correspondents (BCs):- The BC/BF model is a model which based on information and communication technology (ICT). In this model the intermediaries or BC/BFs are technologically empowered by the banks to provide the last mile delivery of financial products and services. Initially created by the banks themselves and later with improvisations and RBI policy support, the model on the back of innovative technologies is bridging the connectivity gap between the service seekers, i.e., under-served public, and the service providers, i.e., the banks. However, a number of issues both for the partner banks and also for the regulators have surfaced since the start of this model. Some of them being
a. Profitability of the $\mathrm{BFs} / \mathrm{BCs}$
b. Banks and their BFs/BCs are exposed to huge risk of cash management
c. The training and hand-holding of the $\mathrm{BFs} / \mathrm{BCs}$ to enhance the trust level of the end customers
d. Adoption of technology
e. Compatibility and integration of technology used by the banks and their BFs/BCs.

Based on above facts, the banks have started coming up with the concept of ultra small branches to provide support and supervise work of certain number of BFs/BCs. Also banks could have in-house model where BF/BC outfits could be a subsidiary with its own structure but under closer supervisory control.

\subsection{Regulatory Approach:}

i. Simplified KYC Norms: - Under current KYC norms, a customer has to provide number of documents for opening an account as per RBI guidelines. However, the people living in rural areas face problem in fulfilling these norms. To enable banks to tap in this huge opportunity of rural banking in unbanked 
areas and to meet the objective of financial inclusion, RBI has relaxed a number of norms for accounts opened by people who plan to keep balances not exceeding Rs.50, 000 and whose total credit in all the accounts taken together is not expected to exceed Rs.100, 000 in a year. Small accounts can now be opened on the basis of an introduction from another account holder who has satisfied all the KYC norms.

ii. Simplified bank saving account opening: - The account opening form has been simplified to ease the opening of account by the poorer sections, street hawkers and other migratory labours of the society.

iii. Bank branch authorization: - RBI has permitted banks to open branches without taking authorization, thus deviating from its normal norms, in tier 3 to 6 city, towns, or villages. This would enable the government, regulator and the banks to speed up the drive for financial inclusion and this make available the financial services to the unbanked population of the country.

\subsection{Technology Based approach:}

i. Mobile Banking :- One of the most remarkable developments in terms of innovation in order to harness the full power of technology, the banks have tied up with mobile operators to provide financial services like bill and utility payment, fund transfer, ticket booking, shopping etc. Some examples of this model are m-Pesa by Vodafone and Airtel Money.

ii. Kiosk / ATM based banking: - In some states, the state government has taken initiatives for providing kiosk based model for access to financial services. Also banks have used the technology to enable their ATMs to virtually act like a $24 \times 7$ branches.

iii. Branchless Banking: - Some of the leading banks have come up with this concept where there would be an online system with chat facility assisting the person to make use of various electronic machines for depositing and withdrawing cash and cheques. However this initiative is in a very initial stage and has a limitation in terms of initial Cost for banks and literacy / knowledge for the rural population and hence this concept is currently limited to urban and semi-urban areas.

iv. Aadhaar Enabled payment services:- In this system, any Indian citizen having an Aadhaar number updates his account with the same. All accounts having aadhaar number updated are to be reported to $\mathrm{RBI}$, which in turn reports it to various government departments. While making payments to people for working under initiatives like MGNREGA or various subsidy schemes, the departments use this information for directly crediting the money to the beneficiary's account. This not only reduces the delay in the benefits being received by the end user, but also reduces the chances of corruption in the distribution of the benefits under schemes. Also the unique biometric identification data stored in the Aadhaar database is expected to empower a bank customer to use Aadhaar as his/her identity to access various financial services. A pilot scheme in four districts of Jharkhand state is currently being carried out under which MGNREGA wages to labourers are credited to their Aadhaar enabled bank accounts.

\subsection{Knowledge Based Approaches}

Financial education, financial inclusion and financial stability are three elements of an integral strategy to empower people to make effective use of the financial services network. While financial inclusion works from supply side, financial education feeds the demand side by promoting awareness among the people regarding the needs and benefits of financial services offered by banks and other institutions. These two strategies together promote greater financial stability.

Figure 4: The Financial Tripod

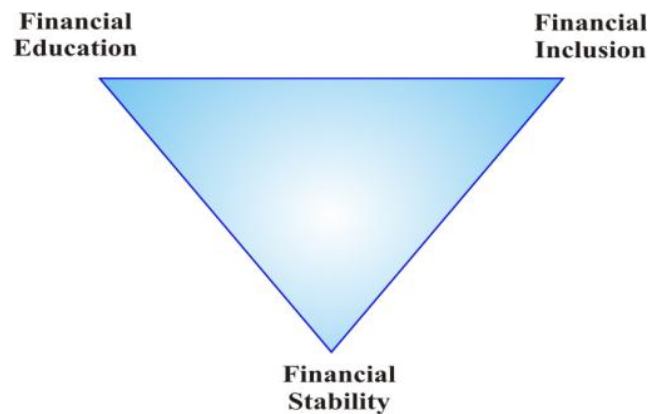

i. Financial Stability Development Council (FSDC) has explicit mandate to focus on financial inclusion and financial literacy simultaneously.

ii. RBI had issued guidelines on the financial literacy Centres (FLC) on in June 2012 for setting up FLCs. It was advised that the rural branches of scheduled commercial banks should increase efforts through conduct of outdoor Financial Literacy Camps at least once a month. Accordingly, 718 FLCs had been 
set up as at end of March 2013. A total of 2.2 million people had been educated through awareness camps / choupals, seminars and lectures during April 2012 to March 2013.

\subsection{Governments Initiatives}

The government has taken various initiatives indirectly through the regulators, government promoted schemes through its various ministries. Some such initiatives have been listed below.

i. Induction of SHG-2:- The original SHG as initialized by NABARD had certain limitations. This led to NABARD preparing a strategy to revitalize the SHG movement leading with the induction of SHG-2 model.

ii. Women SHGs Development Fund: - The Union Budget 2011-2012 proposed a "Women's SHG's Development Fund" with a corpus of Rs. 500 crore. The GoI created this fund to empower women and promote their SHGs. The responsibility of managing the fund is of NABARD. It managed the same through two of its major microfinance funds, namely Financial Inclusion Fund (FIF) and the Financial Inclusion Technology Fund (FITF).

iii. Swarnjayanti Gram Swarozgar Yojana (SGSY):- It is a centrally sponsored scheme that follows the mechanism of forming SHGs of rural poor households, providing capacity building training and linking groups to banks. SGSY is primarily designed to promote self-employment oriented income generating activities for the Below Poverty Level (BPL) households in rural areas.

iv. National Rural Livelihood Mission (NRLM):- Established in June 2010 by the Ministry of Rural Development (MoRD), GoI. It is based on the success of Indira Kranti Patham (IKP), a poverty alleviation program being implemented in Andhra Pradesh. The key strategies of NRLM are to

a. Implement the program with greater emphasis on federations of SHGs

b. Provide flexibilities to states for designing specific action plans for poverty alleviation,

c. Introduce interest subsidy for encouraging repayments of loans and provide multiple doses of credit

d. Improve training and capacity building efforts by setting up skill training institutes in each district

e. Facilitate market linkages and

f. Improve monitoring and evaluation process.

v. The Mahatma Gandhi National Rural Employment Guarantee Scheme (MGNREGS):- This scheme aims to enhance the livelihood of the rural people by guaranteeing at least one hundred days of wage employment in a financial year to a rural household whose adult members volunteer to do unskilled manual work. As the payments are made through the bank/post office accounts, in 2010-11, nearly 10 crore bank/post office accounts have been opened.

vi. Aadhaar- Unique Identification Authority of India (UIDAI):- The GoI has embarked an initiative to provide an individual identification number to every citizen of India and in 2009; it established the UIDAI to issue these cards on behalf of the GoI. This number provided by UIDAI will serve as a proof of identity and address, anywhere in India. The Aadhaar number will also enable people to have access to services such as banking, mobile phone connections and other government and nongovernment services in due course. In addition, the UIDAI has introduced a system in which the unbanked population will be able to open an account during enrollment with Aadhaar without going to a bank. The individual will be able to access such bank accounts through a micro-ATM network with large geographic reach.

\section{Performance and Achievements towards reaching out to the unbanked area under Financial Inclusion Plans (All SCBs including RRBs):}

In January 2010, all public and private sector banks adopted board - approved financial inclusion plans (FIPs) for next three years which started April 2010 to march 2013. RBI advised to all SCBs, to incorporates FIPs with their business strategy to financially nurturing to all excluded population in India.

RBI and SCBs have adopted a structured approach to achieve financial inclusion through FIPs containing self set targets with measurable and monitor able outcomes. Below mention table shown last three years considerable performance in the path of financial inclusion. 


\begin{tabular}{|c|c|c|c|c|c|c|c|}
\hline No. & Variable & $\begin{array}{l}\text { Mar- } \\
10\end{array}$ & Mar-11 & Mar-12 & Mar-13 & $\begin{array}{l}\text { Absolute } \\
\text { change } \\
(2010- \\
2013)\end{array}$ & $\begin{array}{l}\text { Percentage } \\
\text { change (2010- } \\
2013)\end{array}$ \\
\hline 1 & Banking Outlets in Villages $>2,000$ & 37,949 & 66,605 & 112,288 & 119,453 & 81,504 & 214.8 \\
\hline 2 & Banking Outlats in Villages $<2,000$ & 29,745 & 49,603 & 69,465 & 149,001 & 119,256 & 400.9 \\
\hline 3 & Banking Outlets in Villages - Branches & 33,378 & 34,811 & 37,471 & 40,837 & 7,459 & 22.3 \\
\hline 4 & Banking Outlats in Villages $-\mathrm{BCs}$ & 34,174 & 80,802 & 141,136 & 221,341 & 187,167 & 547.7 \\
\hline 5 & Banking Outlats in Villages - Other Modes & 142 & 595 & 3,146 & 6,276 & 6,134 & $4,319.70$ \\
\hline 6 & Banking Outlats in Villages - Total & 67,694 & 116,208 & 181,753 & 268,454 & 200,760 & 296.6 \\
\hline 7 & Urban Locations covered through $\mathrm{BCs}$ & 447 & 3,771 & 5,891 & 27,143 & 26,696 & $5,972.30$ \\
\hline 8 & $\begin{array}{l}\text { Basic Savings Bank Daposit Account (BSBDA) through branchas (No. in } \\
\text { million) }\end{array}$ & 60 & 73 & 81 & 101 & 41 & 67.5 \\
\hline 9 & $\begin{array}{l}\text { Basic Savings Bank Deposit Account (BSBDA) through branches (Amt. in } \\
\text { billion) }\end{array}$ & 44 & 58 & 110 & 165 & 120 & 271.5 \\
\hline 10 & Basic Savings Bank Daposit Account (BSBDA) through $\mathrm{BCs}$ (No. in million) & 13 & 32 & 57 & 81 & 68 & 512.4 \\
\hline 11 & $\begin{array}{l}\text { Basic Savings Bank Deposit Account (BSBDA) through BCs (Amt. in } \\
\text { billion) }\end{array}$ & 11 & 18 & 11 & 18 & 8 & 70.4 \\
\hline 12 & BSBDA Total (in million) & 73 & 105 & 139 & 182 & 109 & 147.9 \\
\hline 13 & BSBDA Total (Amt. in ' billion) & 55 & 76 & 120 & 183 & 128 & 232.5 \\
\hline 14 & OD facility availed in Basic Savings Bank Daposit Account (No. in million) & 0.2 & 1 & 3 & 4 & 4 & $2,094.40$ \\
\hline 15 & OD facility availsd in Basic Savings Bank Daposit Account (Amt. in ' billion) & 0.1 & 0.3 & 1 & 2 & 1.5 & $1,450.00$ \\
\hline 16 & $\mathrm{KCC}$ Total (No. in million) & 24 & 27 & 30 & 34 & 9 & 39 \\
\hline 17 & $\mathrm{KCC}$ Total (Amt. in billion) & 1,240 & 1,600 & 2,068 & 2,623 & 1,383 & 111.5 \\
\hline 18 & GCCs Total (No. in million) & 1 & 2 & 2 & 4 & 2 & 161.2 \\
\hline 19 & GCCs Total (Amt. in billion) & 35 & 35 & 42 & 76 & 41 & 117.4 \\
\hline 20 & ICT A Cs-BC Total Transactions (No. in million) & 27 & 84 & 156 & 250 & 224 & 844.4 \\
\hline 21 & ICT A Cs-BC Total Transactions (Amt in ' billion) & 7 & 58 & 97 & 234 & 227 & $3,279.80$ \\
\hline
\end{tabular}

No. of Branches, BCs and other modes of banking outlets in villages:-

Due to RBI's take intensively efforts in financial inclusion areas, the number of bank branches including RRBs increased of from 33,378 in March 2010 to 40,837 in March 2013. Banking outlets through BCs has been also increased from 34,174 in March 2010 to 2,21,341 in March 2013 and other modes of banking outlets in villages has increased rapidly from March 2010 to march 2013.(Figure 5)

Figure 5: No of Branches, BCs and other modes of Banking outlets in Villages

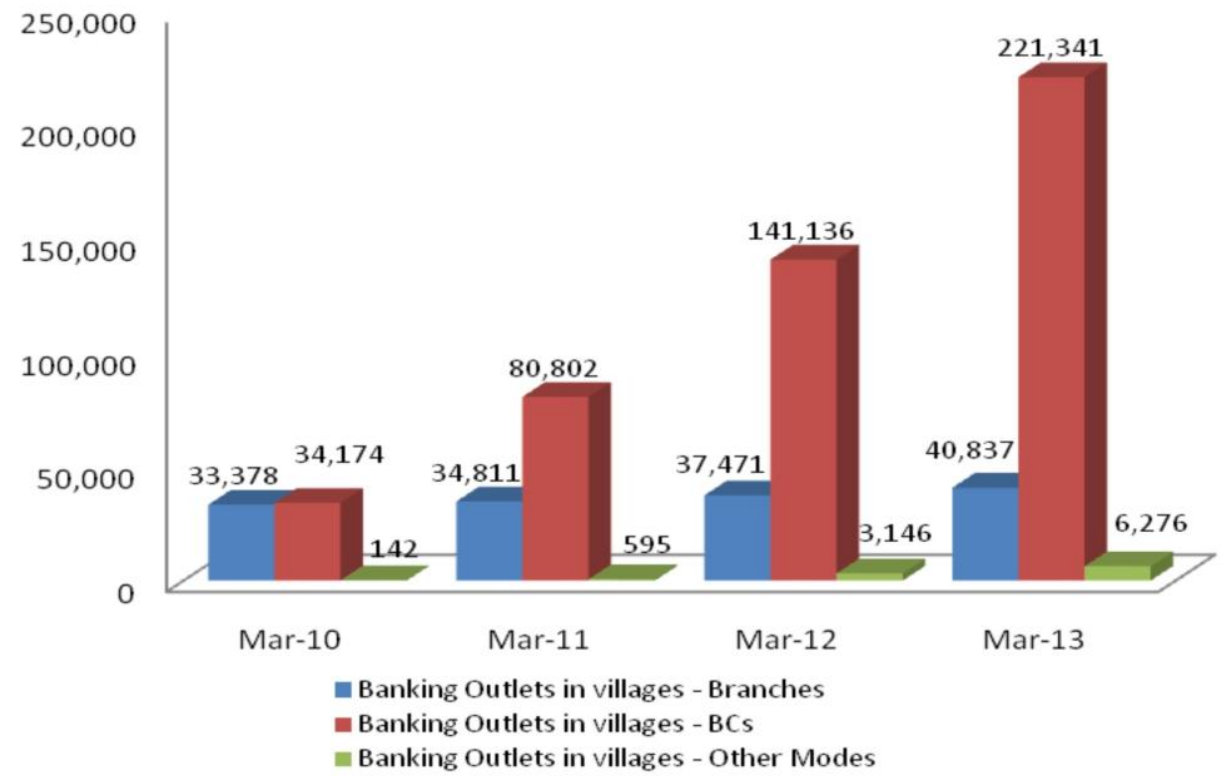

Basic Savings Bank Deposit Account (BSBDA) opened through branches and BCs:-

The number of BSBD accounts opened has been increased from 60 million in March 2010 to 101million in March 2013 through bank branches and BSBD accounts which open by BCs has increased from 13 million in march 2010 to 81 million in march 2013. (Figure 6) 
Figure 6: Basic Savings Bank Deposit Account (BSBDA) opened through Branches and BC



\author{
BSBDA opened through \\ branches
}

BSBDA opened through BCS

RBI also advised to all banks to provide small overdrafts facilities in BSBD accounts. Therefore up to March 2013, 4 million BSBD accounts availed OD facility of 2 billion.

Kisan Credit Cards (KCC) and General Credit Cards (GCC) Issued:-

Under FIPs RBI advised to banks to issue smart cards to farmers for availing timey and adequate credit facilities, up to March 2013 Banks has been issued 34 million KCCs and provided credit (Graph - 3). Banks also provide GCCs to Non - farm entrepreneurs to fulfill their credit needs as per revised guidelines in Dec.'13. Up to March 2013 banks had issue 4 million GCCs. (Figure 7)

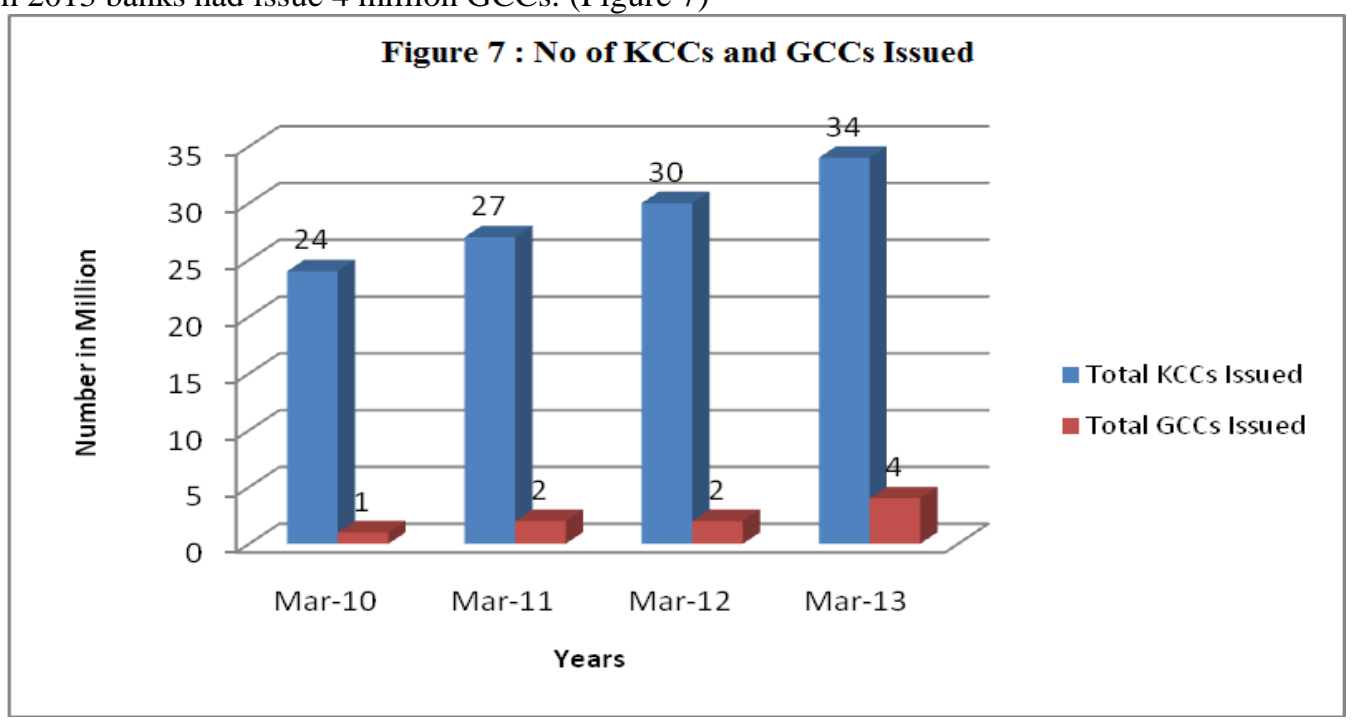

To provide cost effective banking services for excluded areas the RBI suggested, to all SCBs to provide ICT based banking services. The Number of ICT based transactions in year of 2013 is 250 million and amount of these transactions in same year is 234 billion.

\section{Conclusion:}

Even though enough efforts are being made by all stake holders viz Regulator, Government, Financial Institutions and others, the efforts are not yielding the kind of result expected. The regulator has to create a suitable regulatory environment that would keep the interest of all the stakeholders.

The concern of banks about profitability is to be addressed by the regulator as the entire process of financial inclusion would be a kind of social work in the first few years. The concerns of the government about the reach, feasibility and implementation of government policies to the last mile needs to be addressed. The easy availability of financial services to the last mile user, the people in tier 3 to tier 6 in entirety needs to be addressed.

The bank's concerns can be addressed by leveraging ICT, designing innovative products and service models. A structured expansion and appropriate regulatory norms addressing the bank's concern and inclusion 
of NBFCs, MFI and SHG in the last mile connectivity of people to financial services could resolve the people's concern. Also bank use intensive mobile banking services to deliver banking and financial services to the people.

For achieve targets of FIP, it's needs to empowering MSMEs through provide timely and adequate finance because MSME's are the best medium for achieving inclusive growth which generate local demand and consumption, provide employment to millions of fresher's.

The aadhar card could be the answer to the government's concern as the bank accounts can be linked to the holder's aadhar number; however the sheer scale makes it difficult. Alternate to the same could be use of the vast postal office network at the disposal of the government. The post offices can easily reach the end user and vice-versa as the infrastructure is already in place. Regulatory bodies, banks and Government should intensively work on create awareness by educating people about finance.

Thus, Innovative products, out of the box service models, effective regulatory norms and leveraging technology together could change the landscape of the current progress of the much needed and wanted, Financial Inclusion Program.

\section{Reference}

[1]. N.Mehrotra, V. Puhazhendhi, G. Nair G, B. B. Sahoo, Financial Inclusion - An overview(Occasional Paper - 48), Department of Economic Analysis and Research \& National Bank for Agriculture and Rural Development, Mumbai, 2009, 1-24.

[2]. C Rangarajan, Report of the committee on Financial Inclusion, 2008,1- 31

[3]. Report of Financial service provision and the prevention of financial exclusion, Report of European Commission,2008 ,1-10

[4]. D. Goodwin, L. Adelman, S. Middleton and K. Ashworth, debt, money management and access to financial services: evidence from the 1999 PSE survey of Britain (Working Paper - 8), Poverty and Social exclusion survey of Britain Centre for Research in Social Policy, 1999, 1- 6.

[5]. Asli Demirguc-Kunt and Leora Klapper, Measuring Financial Inclusion: The Global Findex Database, World Bank policy research Working paper $6025,2012,1-61$

[6]. A Little data book on Financial Inclusion 2012, The World Bank, 2012, 2-74. retrieved from: http://data.worldbank.org/products/data-books/little-data-book-on-financial-inclusion

[7]. Demirguc-Kunt, Asli; Klapper, Leora; Randall, Douglas, The Global Findex database : financial inclusion in India, Findex notes ; no. 8., The World Bank,2013,1-6. retrieved from : http://documents.worldbank.org/curated/en/2013/02/18477245/global-findexdatabase-financial-inclusion-india

[8]. A. Thapar, A study on the effectiveness of the financial inclusion program in India, VSRD International Journal of Business and Management Research, 3 (6) , 2013, 211-216.

[9]. K.C. Chakrabarty, Presentation on Financial Inclusion at St Xavier's college, Sep. 2011, 3-18. retrieved from: http://rbidocs.rbi.org.in/rdocs/Speeches/PDFs/FIC060911DG.pdf

[10]. P. Bakshi, Financial Inclusion - BC/BF model - what's new?, The Journal of Indian Institute of Banking \& Finance,83(2), 2012,510. Retrieved from: http://www.iibf.org.in/documents/IIB-Bank-Quest-april-june-12.pdf

[11]. M.M.Gandhi, Financial inclusion in India - issue and challenges, International Multidisciplinary Journal of Applied Research, 1(3), 2013, 12-20.

[12]. Ramnath Pradeep, A. Garg, Financial Inclusion - Viable Opportunities in India, 4-39. Retrieved from: http://books.google.co.in/books?id=WcCXBT4AQeIC

[13]. Raghuram G. Rajan, A hundred small steps, Report of the Committee on Financial sector reforms (Planning Commission Government of India), 2009, 50-53.

[14]. D. R. K. Reddy, Financial inclusion: Road Ahead, The Journal of Indian institute of Banking \& Finance, 2012, 40-45.

[15]. Deepti KC, Financial Inclusion: Government Promoted Initiatives, Institute for Financial Management and Research Centre for Microfinance Thematic Fact Sheet 8,2-8. Retrieved from: (http://www.ifmrlead.org/cmf/wpcontent/uploads/attachments/csy/3166/Govt\%20Financing-FS.pdf)

[16]. Annual Report 2012-13, Reserve Bank of India, 2013, 76-80.retrieved http://www.rbi.org.in/scripts/AnnualReportPublications.aspx?Id=1082)

[17]. http://www.rbi.org.in/scripts/NotificationUser.aspx?Id=8603\&Mode=0\#an

[18]. N. Dangi, P.K. Kurukshetra, Current Situation of Financial Inclusion in India and Its Future Visions, Kurukshetra in International Journal of Management and Social Sciences Research, 2( 8), 2013,155-157.

[19]. Deepali Pant Joshi, Financial Inclusion, RBI Monthly Bulletin November 2013,133-135; retrieved from: http://www.rbi.org.in/scripts/BS SpeechesView.aspx?Id=853

[20]. Report on Trend and progress of banking in India 2012-13, Reserve Bank of India, 2013,83-87.

[21]. Retrieved from: http://rbidocs.rbi.org.in/rdocs/Publications/PDFs/0RTP21112013_F.pdf

[22]. P. V. Bhaskar, Financial Inclusion in India-An Assessment, RBI Monthly Bulletin January 2014, 30-32. retrieved from: http://www.rbi.org.in/scripts/BS SpeechesView.aspx?Id=862 